\title{
POLEMIK QANUN ACEH DALAM KONSTRUKSI MEDIA ONLINE ANTARANEWS.COM
}

\author{
Yuhdi Fahrimal \\ Program Doktor Komunikasi Pembangunan Pertanian dan Pedesaan \\ Institut Pertanian Bogor dan Awardee BUDI-DN LPDP-DIKTI \\ e-mail:fahrimalhazmi@gmail.com
}

\begin{abstract}
Post-MoU, the conditions for peace in Aceh still remain in a dilemma. This happened because the differentiation principle of self-governement between the central government and the Aceh government. One of the problems that unfinished is the Qanun Flag and Coat Aceh. This study aimed to analyze the media construction (antaranews.com) to the polemic Qanun Aceh. The approach used in this study is a constructivist-critical analysis model framing. The results showed that antaranews.com constructing the cause of polemic occurs because the Aceh Governmet endorsed the Aceh Qanun about flag and emblem Aceh that closely resembles the GAM flag. The Aceh Government placed as the guilty party. As a government-owned media, antaranews.com helped push for the Government to revise Aceh Qanun Number 3/2013.
\end{abstract}

Keywords : media construction, polemic of local regulation, framing

\begin{abstract}
ABSTRAK
Pasca-MoU Helsinki, kondisi perdamaian di Aceh masih tetap berada dalam posisi dilematis. Hal ini terjadi karena masih adanya perbedaan prinsip self-governement antara pemerintah pusat dan Pemerintah Aceh. Salah satu yang masalah yang belum selesai adalah pengesahan Qanun Bendera dan Lambang Aceh. Penelitian ini bertujuan untuk menganalisis konstruksi media (antaranews.com) terhadap polemik pengesahan Qanun Aceh. Pendekatan yang digunakan dalam penelitian ini adalah konstruktivis-kritis dengan model analisis framing. Hasil penelitian menunjukkan bahwa antaranews.com mengonstruksi penyebab polemik terjadi karena Pemerintah Aceh mengesahkan Qanun Bendera dan Lambang Aceh yang sangat menyerupai bendera GAM. Pemerintah Aceh ditempatkan sebagai pihak yang bersalah. Sebagai media yang dimiliki oleh pemerintah, antaranews.com ikut mendorong agar Pemerintah Aceh melakukan revisi terhadap Qanun Aceh Nomor 3 tahun 2013.
\end{abstract}

\section{Kata Kunci : konstruksi media, polemik peraturan daerah, framing}

\section{PENDAHULUAN}

Aceh pasca-MoU Helsinki belum sepenuhnya berada dalam kondisi damai. Hal ini mengingat masih banyak aturan dan kesepakatan dalam MoU Helsinki dan Undang-undang Pemerintah Aceh yang masih dianggap bermasalah. Hal 
ini dapat terjadi sebagai akibat dari masih adanya kecurigaan antara pusat dan daerah kepada elite politik Aceh yang sebagian besar dikuasai oleh mantan kombatan Gerakan Aceh Merdeka (GAM) (Djumala, 2013). Salah satu masalah yang mencuat dan menimbulkan ketegangan antara Pemerintah Aceh dan Pemerintah Pusat adalah pengesahan Qanun Aceh Nomor 3 Tahun 2013 tentang Bendera dan Lambang Aceh. Polemik ini terjadi sebagai akibat dari ketidaksesuaian interpretasi dan implementasi perjanjian damai (MoU Helsinki) dan UU Pemerintah Aceh. Pemerintah Pusat menolak menerima Qanun Bendera dan Lambang Aceh karena menyerupai Bendera dan Lambang GAM. Sementara di pihak Pemerintah Aceh, Qanun Bendera dan Lambang Aceh sudah sesuai dengan kehendak seluruh rakyat Aceh yang menjadi landasan nilai-nilai perjuangan rakyat Aceh (Fahrimal, et al., 2014; Nyarwi, 2011).

Dalam ranah media, kotroversi kebijakan antara dua kelompok elite politik-pusat dan daerah menjadi nilai berita yang sangat penting. Nilai-nilai berita ini menjadi komiditi yang laku jika dijual kepada publik (Lee et al., 2008). Pertarungan wacana yang diproduksi oleh elite politik dalam media memiliki nilai berita yang dapat menarik perhatian publik, khususnya berkenaan dengan konflik dan kontroversi (Weldon, 2009 dan Cramer, 2011). Mengikuti logika ekonomi-politik media, semua yang dapat memberikan keuntungan bagi media akan diproduksi secara massif. Untuk mempermudah mengemas isu, media melakukan konstruksi isu (van Gorp, 2007; Weaver, 2007) serta mendistribusikannya ke ruang publik dalam dua posisi biner yang saling bertentangan (Mosco, 2009).

\section{KERANGKA PEMIKIRAN}

Media Massa Sebagai Aktor Politik dan Agen Konstruksi

Media dapat dipahami sebagai sarana dimana pesan yang sama dan seragam dipancarkan oleh pengirim yang terpusat kepada khalayak secara sistematis (Castells, 2001). Dalam makna ini, media disebut hanya sebagai alat dimana informasi ditrasmisikan kepada khalayak. Perkembangan teknologi telah membawa media ke arah konvergensi dengan ciri interaktivitas, interkonektivitas, dan intermediasi. Berbagai media tradisional -surat kabar, radio, dan televisi-dipaksa untuk masuk ke dalam era baru ini. Kehadiran internet atau hypermedia space (Kraydi, 2010) telah ikut mengubah berbagai pola konsumsi media -meskipun media tradisional tidak ditinggalkan sama 
sekali -karena kemudahan akses yang ditawarkan oleh new media (Straubhaar et al., 2012).

Dalam kaitannya dengan ranah politik dan pembangunan, media telah mewujud seperti yang dikatakan oleh Jurgen Habermas sebagai ruang publik atau publicsphere (Hardiman, 2010). Ruang publik adalah ruang dimana para masyarakat-warga berinteraksi satu sama lain, saling memproduksi diskursus, dan berada dalam posisi yang egaliter (sama). Dalam konstruksi pemikiran Habermas, ruang publik adalah bagian dari masyarakat warga (civil society), yaitu, masyarakat otonom yang mempunyai hak untuk menentukan diri dan mengorganisasi diri, maka ruang publik dipahami sebagai kondisi yang memungkinkan bagi masyarakat untuk turut berpartisipasi. Ruang publik itu sendiri kiranya dapat dipahami sebagai kesempatan bagi masyarakat untuk melakukan dialog rasional.

Dalam pemahaman McQuail (2011) media menjadi wadah dimana gagasan diproduksi dan dipertukarkan. Media massa juga memberikan otonomi dan menjadi arena terbuka bagi debat publik. Salah satu yang menandai keberaan ruang publik adalah mudahnya masyarakat-warga mengakses ruang publik tersebut. Dalam hubungannya dengan realitas sosial, media massa sebagai ruang publik seharusnya menjadi kawasan netral dimana akses terhadap informasi yang memengaruhi publik tersedia secara luas, diskusi bebas dari dominasi, dan semua orang yang berpartisipasi berada dalam basis kesetaraan dalam ruang publik. Inilah ciri-ciri dari ruang publik itu sendiri. Media massa harusnya hadir dan memfasilitasi proses tersebut dengan memberikan sebuah arena perdebatan publik dan menyatukan warga secara individual sebagai public body dalam opini publik (Rahardjo, 2008).

Gagasan bahwa media merupakan unsur terpenting dalam dinamika politik, tidak dapat dilepaskan dari pengkajian terhadap posisi media dalam relasinya dengan publik (rakyat). Dalam negara demokrasi, rakyat merupakan unsur terpenting dan tidak dapat diabaikan begitu saja. Terkait dengan relasi media dan publik dalam iklim demokrasi dapat dilihat dalam tiga aspek, yaitu, Pertama, media menjadi ruang publik bagi terjadinya interaksi politik ikut mempengaruhi pembentukan sistem komunikasi politik di kalangan publik. Pembentukan karakter dan agenda politik berlangsung yang secara terbuka; Kedua, media tidak hanya menjadi cermin dari kehidupan politik tetapi melakukan generalisasi realitas politik, mengkonstruksi realitas politik sebagai 
sesuatu yang bersifat kompleks dan mengundang antusiasme respon publik; Ketiga, konstruksi realitas media atas dunia politik secara aktif akan memperkuat komitmen pencapaian tujuan politik ideal dari partai politik atau politisi dan kontrol publik yang tajam atas proses itu (Meyer, 2002).

Terkait dengan tanggungjawab media, McQuail (2011) menyatakan bahwa esensi dari keberadaan media adalah tanggung jawab sosial pada kehidupan sosial, budaya, dan politik serta memberikan manfaat positif bagi publik. Untuk dapat melihat hal tersebut, maka perlu dipahami beberapa peran media massa dalam masyarakat (McQuail, 2011), yaitu: pertama, media sebagai windows on events and experience. Media dipandang sebagai jendela yang memungkinkan khalayak melihat" apa yang terjadi di luar sanaataupun pada diri mereka sendiri. Kedua, media sebagai a mirror of events in societyand the world, implying a faithful reflection, yaitu, cermin berbagai peristiwa yang ada di masyarakat dan dunia yang merefleksikan apa adanya. Karenanya, para pengelola media sering merasa tidak "bersalah" jika isi media penuh dengan kekerasan, konflik, dan berbagai keburukan lain, karena memang menurut mereka faktanya demikian, media hanya sebagai refleksi fakta, terlepas dari suka atau tidak suka. Padahal, sesungguhnya angle, arah, dan framing dari isi yang dianggap sebagai cermin realitas ini diputuskan oleh para profesional media, dan khalayak tidak sepenuhnya bebas untuk mengetahui apa yang inginkan. Ketiga, media massa sebagai filter atau gatekeeper yang menyeleksi berbagai hal untuk diberi perhatian atau tidak. Media senantiasa memilih isu, informasi, atau bentuk content yang lainberdasarkan standar para pengelolanya. Di sini khalayak "dipilihkan" oleh media tentang apa-apa yang laik untuk diketahui dan mendapat perhatian. Ke-empat, Media massa dipandang sebagai guide (penunjuk jalan) atau interpreter yang menerjemahkan dan menunjukkan arah atas berbagai ketidakpastian atau alternatif yang beragam. Kelima, media massa sebagai forum untuk mempresentasikan berbagai fenomena dan ide-ide kepada khalayak, sehingga memungkinkan terjadinya tanggapan dan umpan balik. Ke-enam, media sebagai interlocutor yang tidak hanya sekadar tempat berlalulalangnya informasi, tetapi juga partner komunikasi yang memungkinkan terjadinya komunikasi yang efektif.

Berbagai peran media yang kemukakan oleh McQuail (2011) tersebut telah menjadi dasar bagi 
penelitian ini dibuat. Pandangan terhadap media sebagai gatekeeper telah menegaskan bahwa ada realitas lain di balik media yang sengaja ditutupi dari khalayak luas. Meskipun seiring berkembangnya teknologi yang berdampak pada peningkatan kecerdasan masyarakat terhadap media dan politik, namun kondisi ini justru mempermudah pembentukan opini publik di masyarakat. Opini publik dapat dimaknai sebagai pendapat umum dari masyarakat tentang sesuatu hal yang sedang dipikirkan dan dibicarakan. Sebagai institusi citra, media massa memiliki kekuatan untuk membentuk dan menggiring opini publik sesuai dengan kehendak media.

Konstruksi media dapat berpengaruh terhadap opini publik. Pemikiran ini tidak hanya didasarkan pada massifnya penggunaan media oleh publik, namun juga karena media merupakan agen konstruksi yang menggunakan jalur informasi publik untuk menyebarkan berbagai fakta dan peristiwa. Penonjolan aspek tertentu akan berdampak sangat besar bagi gerakan masyarakat (social movement) pada level grassroot. Apapun yang dibicarakan oleh masyarakat setiap hari adalah isu-isu yang disebarkan oleh media (Young dan Soroka, 2012).
Media juga dianggap sebagai aparatus ideologi dimana media membawa kepentingan pemilik yang berjalinkelindan dengan ideologinya, yang cenderung dilakukan oleh Negara. Ideologi tersebut dapat tercermin dari isi berita yang disiarkan media. Masyarakat dipaksa untuk menyaksikan hal-hal yang kadang-kadang belum tentu “dibutuhkan" oleh publik. Dalam hal ini tidak berlebihan jika kita menyebutkan bahwa media tidak hanya dijadikan mesin perah uang oleh pemiliknya, namun juga mesin "pendulang" suara pemilik yang menjadi elite politik (Nurhasim et al, 2009). Jatuh bangun citra politisi di mata publik dikonstruksi oleh berbagai pemberitaan media. Sayangnya, apa yang dikenal oleh orang banyak sebagai objektivitas dalam media, hampir tidak ada (Manan, 2010; Ishadi, 2015).

Dalam realitas politik, media tidak dapat dipandang hanya sebagai penyampai informasi, lebih dari itu media massa juga berperan sebagai aktor politik (McNair, 2011). Media massa dan orang-orang yang bekerja di dalamnya -tidak saja menyampaikan pesan-pesan politik namun juga mengubahnya melalui berbagai proses pemberitaan dan interpretasi. Hubungan antara media dan proses politik bersifat dialektika, melibatkan aksi dan reaksi. 
Media melaporkan dan menganalisis kegiatan politik, di sisi lain media juga merupakan bagai dari pada proses tersebut. Dalam pemahaman ini McNair (2011) menyatakan bahwa media merupakan sumber daya bagi pelaku dan penasihat politik.

Media tidak hanya memberikan pengetahuan kognitif -yang menginformasikan tentang apa yang terjadi -namun, media juga menata dan menyusun realitas politik, memilahmilah peristiwa yang lebih atau kurang penting sesuai dengan keberadaan atau ketiadaannya pada agenda media (McNair, 2011). Proses pemilahan dan pemilihan media ini dikenal sebagai proses konstruksi media (Eriyanto, 2012). Dalam proses konstruksi media, dua hal penting yang perlu diperhatikan adalah (1) seleksi isu dan (2) pembentukan berita (Fishman, 1980 sebagaimana dikutip Eriyanto, 2012). Entman (1993 dan 2007) menggunakan terminologi penonjolan fakta untuk menyebut proses penulisan berita oleh jurnalis.

Dalam melakukan konstruksi, media menggunakan bahasa yang didalamnya terkandung berbagai makna dan ideologi. DeFleur memandang media massa memiliki berbagai cara memengaruhi bahasa dan makna; mengembangkan kata-kata baru beserta makna asosiatifnya; memperluas makna dari istilah-istilah yang ada; mengganti makna lama sebuah istilah dan makna baru; memantapkan konvensi makna yang telah ada dalam suatu sistem bahasa (Badara, 2012).

Menurut Sujiman dalam Badara (2012), ada tiga tindakan yang biasa dilakukan oleh pekerja media tatkala melakukan konstruksi realitas. Pertama, pemilihan simbol (fungsi bahasa). Apapun simbol yang dipilih akan memengaruhi makna yang muncul. Hal ini bisa dijelaskan melalui teori semiotika. Dalam pandangan semiotika, teks (berita) dipandang dengan penuh tanda, mulai dari pamakaian kata atau istilah, frasa, angka, foto, dan gambar, bahkan cara mengemasnya pun adalah tanda. Kedua, pemilihan fakta yang akan disajikan (strategi framing). Framing dipandang sebagai sebuah strategi penyusunan realitas sedemikian rupa, sehingga menghasilkan wacana. Pembentukan frame itu sendiri didasarkan atas berbagai kepentingan internal dan eksternal media, baik teknis, ekonomis, politis, maupun ideologis. Ketiga, kesediaan memberi tempat (agenda setting). Hal ini berkaitan dengan menyediakan ruang atau waktu untuk sebuah pemberitaan (fungsi agenda setting). 
Proses Konstruksi dan Level Pengaruh Media

Proses konstruksi merupakan proses dalam ruang berita (newsroom). Berbagai kepentingan yang saling berhubungan dalam media telah membuat proses konstruksi dan framing dengan memihak kepada elite politik adalah sebuah kelaziman. Terkait dengan proses konstruksi media dan efeknya, Scheufele (1999) mengajukan sebuah model proses dari efek framing yang ditandai oleh tiga jenis aktor, yaitu, (1) sumber yang berkepentingan dan organisasi media; (2) jurnalis (media); dan (3) khalayak. Menurut Scheufele (1999) kita berhadapan dengan dua jenis kerangka dalam media, yaitu, kerangka media dan kerangka individu. Kedua jenis kerangka tersebut dapat bersifat dependen (sebagai efek) atau bersifta independen (sebagai penyebab).

Lebih lanjut Scheufele dan Tewskbury (2007) memberikan pemahaman tentang bagaimana proses framing bekerja dalam lingkungan sosial, yaitu, pertama konstruksi dan penggunaan kerangka media oleh jurnalis dan pihak lain yang bekerja di perusahaan berita. Mereka bekerja di bawah tekanan yang terus menerus dan rutinitas untuk berhadapan dengan sumber berita serta terikat pada ketatnya "nilai berita" dan "angle berita" dalam melaporkan peristiwa. Kedua, transmisi dari laporan berita yang "diberikan kerangka" dari sumber peristiwa kepada khalayak, misalnya pandangan sinis dari politisi. Ketiga, ada penerimaan kerangka tertentu oleh anggota khalayak dengan konsekuensi atas sikap, pandangan, dan perilaku mereka.

Untuk saat ini-dan mungkin untuk masa yang akan datang -media massa dan orang-orang yang bekerja di dalamnya selalu berada dalam dua tekanan yang secara kuat saling berentangan. Pertama, perwujudan idealisme media dan jurnalis. Idealisme hadir dalam bentuk yang disebut oleh Bill Kovach dan Tom Rosientiel (2001) sebagai elemen dari jurnalisme. Bagi Kovach dan Rosientiel (2001) jurnalis haruslah memprioritaskan kebenaran dalam setiap produk beritanya, lotalitas jurnalis (media) hanya kepada publik, dalam produksi berita jurnalis harus mengedepankan aspek verifikatif atau cover both side. Di samping itu, Kovach dan Rosientiel (2001) juga menekankan bahwa jurnalis (media) harus independen dalam produksi berita -tidak boleh memihak kepada siapapun, jika pun harus memihak maka keberpihakan harus pada kebenaran dan itu dimiliki oleh masyarakat.

Kedua, kenyataan bahwa media adalah entitas bisnis serta industri yang 
tergantung pada semangat bisnis yang kuat. Semangat bisnis mendorongnya untuk menyusun agenda dan mengonstruksi realitas yang diperolehnya sehingga menarik untuk ditawarkan ke pasar (market driven orientation) (Ishadi, 2014; Mosco, 2009). Logika ekonomi untuk mendapatkan keuntungan sebesar-besar telah ikut menyumbangkan tekanan besar bagi ruang redaksi media. Persaingan media yang semakin ketat turut menyumbang kekuatan bagi logika ekonomi ini.

Pun diperparah oleh realitas bahwa beberapa pemilik media adalah tokohtokoh politik, sehingga memisahkan media -khususnya media mainstream dari jerat-jerat keberpihakan. Perspektif ini menempatkan produksi berita sebagai suatu proses pertarungan berbagai kelompok di ruang berita. Aspek-aspek yang dipertarungkan dapat menyangkut ideologi dan kepentingan ekonomi, sehingga berita hasilnya dipandang sebagai simbol-simbol yang mencerminkan dominasi ideologi dan kepentingan ekonomi dari kelompok yang memenangkan pertarungan tersebut. Sebab, hanya mereka yang menjadi kelompok dominan saja yang pada akhirnya lebih leluasa untuk mengonstruksi realitas yang dikehendaki sesuai kepentingannya. Secara teknis, hal itu dapat dilakukan dengan cara memanipulasi realitas itu sendiri atau mengondisikan orang lain agar memiliki kesan tertentu terhadap realitas yang ditampilkannya (Ishadi, 2014).

Pertanyaannya kemudian adalah kekuatan apa saja yang mempengaruhi konstruksi realitas media? dan bagaimana bentuk tekanan yang diberikan sehingga berdampak pada konstruksi realitas media? Untuk menjawab hal tersebut, Pamela J. Shoemaker dan Stephen D. Reese (1996) menyumbangkan konsep lima level pengaruh dalam media. Pertama, Individual Level menyangkut sisi profesional jurnalis. Faktor yang melingkupi, antara lain latar belakang pendidikan, perkembangan profesional dan keterampilan dalam menyampaikan berita secara tepat, perilaku individu jurnalis, pemahaman terhadap nilai dan kepercayaan, serta orientasi profesional jurnalis.

\section{Kedua, Media Routine Level} berkaitan dengan perspektif organisasi media, aturan yang berlaku menyangku proses penentuan berita atau bagaimana proses gatekeeping-nya. Gitlin (1980) seperti dikutip Shoemaker dan Reese (1996) percaya jika rutinitas wartawan menjadi penyebab beberapa frame harus diseleksi seringkali dari pada yang lain. Lebih lanjut, kepemilikan dan logika 
ekonomi dari organisasi berita sangat potensial menyebabkan konflik kepentingan (interest conflict) dengan prosedur jurnalistik yang dimiliki personal wartawan. Ketiga, Organization Level menyangkut faktor struktur organisasi media, termasuk pengaruh dari pemimpin redaksi, para editor, dan kebebasan (independensi) wartawan saat bekerja (Van Gorp, 2007).

Keempat, extramedia level adalah faktor-faktor di luar media yang menyangkut faktor sosial-ekonomibudaya-politik, tekanan dari pemerintah, hingga pemilik modal. Kondisi ini membuat media menjadi pion politisi dan industriawan untuk mencari keuntungan. Dengan kata lain, atas nama kepentingan bangsa, para pejabat mengatur pemberitaan sesuai keinginan mereka. Adapun atas nama pertumbuhan ekonomi, para pebisnis atau pedagang melakukan hal yang sama (Subiakto dan Ida, 2012). Level extra-media terkait dengan tiga faktor utama, yaitu, (1) narasumber berita mempunyai kepentingan tertentu yang lewat kampanye public relations dan pressure group dapat memengaruhi proses-proses konstruksi realitas; (2) revenue resources atau sumber penghasilan media, berupa iklan, pelanggan, maupun khalayak melalui sistem rating, ikut berkontribusi pada proses konstruksi realitas media; dan (3) lembaga lain di luar media, seperti kalangan bisnis, pemerintah, ekonomi, maupun teknologi (Ishadi, 2014).

Kelima, Ideological Level diartikan sebagai kerangka-kerangka referensi yang terintegrasi, di mana masing-masing individu melihat realitas dan bagaimana individu-individu bertindak terhadap realitas yang ada. Level ideologi menyoroti pihak yang berkuasa di masyarakat, serta bagaimana kekuatan itu berperan dalam menentukan agenda media. Berita merupakan struktur narasi yang membawa ideologi. Menurut John Fiske (2012) ideologi dapat dipahami sebagai proses umum produksi makna dan gagasan. Ideologi berkaitan dengan pandangan atau sistem keyakinan yang dipercaya oleh suatu masyarakat. Raymond Williams (seperti dikutip oleh Fiske, 2012) mengemukakan tiga penggunaan utama ideologi, yaitu, (1) sebuah sistem karakteristik kepercayaan dari suatu kelas atau kelompok tertentu; (2) sebuah sistem kepercayaan palsu ide atau kesadaran palsu- yang dapat dikontraskan dengan kebenaran atau pengetahuan; (3) proses umum dari produksi makna dan ide.

Semua pengaruh yang hadir dalam berbagai level tersebut telah meruncingkan perdebatan terkait media 
dan politik ke arah objektivitas dan subjektivitas dalam media. Bagi banyak orang, media dituntut untuk objektif. Standar yang digunakan adalah bahwa media harus mampu melihat dari posisi yang seimbang dan sesuai dengan fakta. Mengikuti pendapat Kovach dan Rosientiel (2001) bahwa jurnalis yang objektif adalah jurnalis yang mengedepankan hati nurani dalam meliput dan menulis berita. Objektifitas selalu dikaitkan dengan ketidakberpihakan media dan jurnalis pada satu pihak. Oleh karenanya cover both side menjadi kata kunci yang harus dipegang teguh oleh media dan pekerja di dalamnya. Di sisi lain, pandangan konstruktivisme-kritis memandang tidak ada standar objektivitas dalam media. Semua isi media dipengaruhi oleh subjektivitas dari jurnalis. Muncul adagium bahwa objektifitas media adalah subjektifitas itu sendiri.

\section{TUJUAN PENELITIAN}

Tulisan ini bertujuan untuk melakukan pembongkaran teks media melalui analisis framing. Teks media yang akan dianalisis merupakan pemberitaan seputar polemik pengesahan Qanun Bendera dan Lambang Aceh yang di-publish oleh situs berita online antaranews.com. Analisis framing menjadi penting dalam studi komunikasi khususnya dalam kaitannya dengan politik dan kebijakan karena media dianggap bukanlah sebuah entitas netral. Ruang berita bukan menjadi ruang hampa nilai (Weaver, 2007; Entman, 1993, 2007). Berbagai pengaruh berupaya menekan pola kerja wartawan di ruang media sehingga berita yang dibuat cenderung memihak kepada salah satu pihak dan mengabaikan pihak lainnya (Shoemaker dan Reese, 1996).

\section{METODE PENELITIAN}

Framing pada intinya merujuk kepada usaha pemberian definisi, penjelasan, evaluasi dan rekomendasi dalam suatu diskursus (discourse) untuk menekankan kerangka berpikir tertentu terhadap peristiwa yang diwacanakan media (Entman, 1993; Entman, 2007; Scheufele dan Tewksbury, 2007). Proses konstruksi realitas tidak bisa dipisahkan dari proses pengambilan keputusan di newsroom. Dinamika yang ada dalam newsroom ini telah lama menjadi objek penelitian yang menarik melalui pelbagai pendekatan dan telah menghasilkan sejumlah teori penting. Pelbagai metodologi telah dipakai peneliti yang berupaya menjelaskan secara komprehensif bagaimana dinamika proses produksi dan reproduksi berita. Di antara beberapa metodologi yang ada, analisis bingkai 
(framing analysis) menjadi mata pisau untuk mengetahui bentuk konstruksi realitas media. Mata pisau metodologi ini pula yang dipakai dalam penelitian ini. Analisis Framing lazim digunakan untuk membongkar konstruksi, ideologi, dan politik media (Eriyanto, 2012) khususnya dalam peristiwa polemik, konflik, dan kontroversi (Jerit, 2007; Lee et al., 2008; Birkland dan Lawrence, 2009).

Objek pada penelitian ini adalah teks berita pada situs online antaranews.com dalam rentang waktu Maret-Mei 2013 (dalam masa ini polemik pengesahan Qanun Bendera dan Lambang Aceh mencuat). Setidaknya ada tiga ciri situs berita online atau lazim dikenal sebagai surat kabar digital, yaitu, aktualitas, universalitas, dan interaktivitas. Ciri aktualitas tercermin dari segi informasi yang terus diperbarui setiap saat. Semua informasi yang ada di situs berita online merupakan kejadian teraktual. Hal ini dimungkinkan karena kemudahan akses penyebaran informasi sebagai akibat lain dari lahirnya teknologi gadget yang terintegrasi dengan internet. Keberagaman (universalitas) topik pada surat kabar online dimungkinkan karena tidak ada lagi batasan kapasitas yang dimilikinya. Ciri interaktivitas merujuk pada dimungkinkannya para pengguna atau user dan penyedia informasi memberikan respon atau umpan balik satu sama lain secara langsung (Fuady, 2002).

Metode analisis yang dipakai dalam penelitian ini adalah analisis framing model Gamson dan Modigliani. Konsep utama dari gagasan framing Gamson dan Modigliani terletak pada pergerakan sosial (social movement). Keberhasilan gerakan/protes sosial di antaranya ditentukan oleh sejauhmana khalayak mempunyai pandangan yang sama atas suatu isu, musuh bersama, dan tujuan bersama. Framing memainkan peran penting untuk menghidupkan simbol dan makna dalam gerakan sosial. Simbol dan makna ini digunakan siapa lawan dan siapa kawan serta untuk membentuk solidaritas kolektif dengan merasakan bahwa suatu masalah adalah masalah bersama. Unit analisis framing model Gamson dan Modigliani adalah frame central atau Package yang terdiri atas framing devices -dianalisis melalui methapors, catchphrases, exemplar, depiction, dan visual images. Unit analisis kedua adalah reasoning devices -dianalisis melalui roots, appeals to principles, dam consequences (Eriyanto, 2012). 
HASIL DAN PEMBAHASAN

Polemik Peraturan Daerah Sebagai Sebuah Realitas Politik

Dinamika politik lokal di Aceh pasca-MoU Helsinki selalu diwarnai letupan ketegangan dan kontroversi. Disepakatinya butir-butir yang tertuang dalam Memorandum of Understanding (MoU) tidak lantas membuat hubungan Pemerintah Pusat dan Pemerintah Aceh membaik. Jika dirunut sejarah, pascapenandatanganan MoU Helsinki, tanggal 15 Agustus 2005 di Helsinki, Finlandia setidaknya ada beberapa ketegangan yang melibatkan Pemerintah Pusat dan Pemerintah Aceh. Polemik dan ketegangan dari kedua belah pihak diawali tarik ulur konsep self government dan otonomi khusus, bahkan ketika perundingan Helsinki berlangsung (Nurhasim, 2008; Djumala, 2013). Konsep self government adalah konsep yang ditawarkan oleh pihak GAM terkait pemberian atau perlimpahan kewenangan dalam mengatur pemerintahan sendiri bagi Aceh. Dalam artian lain, self government setingkat lebih tinggi dari otonomi khusus yang diberikan oleh Pemerintah Pusat (Kingsbury, 2005; Aspinal, 2005; Awaluddin, 2009; dan Sujatmiko, 2012).

Meskipun penuh dengan drama tarik ulur ajuan konsep yang laik bagi Aceh, kedua belah pihak sepakat untuk menerima konsep Governing Aceh yang merujuk kepada pengaturan tentang kewenangan dan kepemerintahan Aceh (Djumala, 2013). Untuk mewujudkan butir-butir MoU Helsinki, Pemerintah Pusat mengesahkan Undang-Undang Nomor 11 Tahun 2006 tentang Pemerintah Aceh. Undang-undang ini adalah produk hukum yang telah merangkum seluruh strategi kesejahteraan bagi rakyat Aceh. Namun, capaian dalam MoU Helsinki dan UU Pemerintah Aceh tidak berbuah manis dalam implementasinya. Ketegangan pada proses implementasi amanah MoU Helsinki dan UU Pemerintah Aceh masih diwarnai polemik. Polemikpolemik ini diakibatkan oleh rasa saling curiga baik Pemerintah Pusat maupun Pemerintah Aceh (Djumala, 2013). Pertama, polemik pencalonan Irwandi Yusuf dan Muhammad Nazar pada Pemilihan Gubernur Aceh tahun 2006 melalui jalur independen. Pemerintah Pusat mencurigai bahwa pencalonan ini merupakan representasi dari Gerakan Aceh Merdeka (GAM), mengingat Irwandi Yusuf adalah mantan juru propaganda GAM dan Muhammad Nazar adalah koordinator Suara Referendum Rakyat Aceh (SIRA) yang berafiliasi dengan GAM.

Polemik kedua, saat pembentukan partai politik lokal oleh mantan 
kombatan GAM yang saat itu dinamakan sebagai Partai Gerakan Aceh Mandiri yang disingkat GAM. Menurut Pemerintah Pusat, partai lokal ini masih menggunakan embel-embel GAM sebagai gerakan separatis, sehingga harus diubah jika ingin disahkan menjadi partai lokal oleh Kemenkumham Republik Indonesia. Pada ketegangan ini mantan kombatan GAM melunak dan mengubah nama dan lambang partai menjadi Partai Aceh serta menghilangkan lambang bendera GAM. Partai lokal yang digawangi oleh mantan kombatan GAM dibawah komando Muzakkir Manaf berhasil memenangkan Pemilihan Umum tahun 2009 dengan menempatkan 27 (dua puluh tujuh) kadernya di kursi parlemen Aceh (baca: Dewan Perwakilan Rakyat Aceh). Tahun 2013, melalui dukungan penuh Partai Aceh, Zaini Abdullah dan Muzakkir Manaf berhasil merebut kemenagan sebagai Gubernur dan Wakil Gubernur Aceh tahun 2012-2017.

Ketegangan ketiga, pembentukan Komisi Kebenaran dan Rekonsiliasi sebagai komisi yang berfungsi menyelesaikan "dosa masa lalu" selama Aceh ditetapkan sebagai Daerah Operasi Militer dan Darurat Militer. Menurut penelitian Nivada (2012) pembentukan Komisi Kebenaran dan Rekonsiliasi akan sulit dilakukan di Aceh karena hal ini menjadi suatu problematik di Pemerintah Pusat. Pada hakikatnya keberadaan Komisi Kebenaran dan Rekonsiliasi dibutuhkan untuk memenuhi hak para korban selama perang berkecamuk di Aceh.

Keempat, polemik pengesahan Qanun Aceh Nomor 03 tahun 2013 tentang Bendera dan Lambang Daerah. Sejak dimasukkan ke dalam Lembaran Aceh Nomor 40 tanggal 25 Maret 2013, Qanun Nomor 3 Tahun 2013 tentang Bendera dan Lambang Aceh menuai kontroversi. Pasalnya, Qanun yang seharusnya menjadi kekhususan dan keistimewaan bagi Aceh ini mengadopsi Bendera dan Lambang Gerakan Aceh Merdeka (GAM). Dalam Pasal 4 ayat (7) Qanun Bendera dan Lambang Aceh dijelaskan makna dari Bendera Aceh, sebagai berikut: (1) Dasar warna merah, melambangkan jiwa keberanian dan kepahlawanan; (2) Garis warna putih, melambangkan perjuangan suci; (3) Garis warna hitam, melambangkan duka cita Rakyat Aceh; (4) Bulan sabit berwarna putih, melambangkan lindungan cahaya iman; dan (5) Bintang bersudut lima berwarna putih, melambangkan rukun Islam.

Berdasarkan laporan dari International Crisis Group (ICG), sebuah lembaga yang bergerak di bidang pemantauan politik dan keamanan 
negara-negara dunia mengkaji dampak politik yang ditimbulkan dari pengesahan Qanun Bendera dan Lambang Aceh. Lembaga yang bermarkas di Brussel ini menyebutkan, Partai Aceh -sebagai partai penguasa merasa tidak perlu berkompromi karena para petingginya yakin Jakarta akan tunduk pada keinginan mereka seperti ketika pemilihan kepala daerah 2012 lalu. Dalam laporan yang berjudul Indonesia: Tensions Over Aceh's Flag disebutkan juga bahwa Partai Aceh ingin memanfaatkan kekuatan emosional yang sangat besar dari bendera Aceh untuk memobilisasi pemilih untuk pemilu 2014. Hal ini terbukti jika dilihat tampilan wacana media beberapa calon legislatif (caleg) dari Partai Aceh menjadikan isu Bendera Aceh sebagai bahan kampanyenya (International Crisis Group, 2013).

Partai Aceh, sebut ICG, saat ini sedang membangun kendali terhadap lembaga politik di Aceh. Partai politik lokal yang dibentuk oleh pentolan Gerakan Aceh Merdeka itu sedang mengerahkan pengaruhnya terhadap Pegawai Negeri Sipil dan Komisi Independen Pemilihan (KIP) Aceh. Perdebatan ini lebih dari sekedar soal Bendera Aceh yang merupakan simbol separatis. Menurut ICG, sesungguhnya perdebatan ini adalah tentang ke mana
Aceh akan menuju dan akan seperti apa hubungannya dengan Jakarta. Ini juga menyangkut apa implikasinya buat wilayah lain, seperti Papua, di mana mengibarkan bendera pro kemerdekaan menjadi tindakan paling simbolik untuk aktivis pro kemerdekaan.

Beberapa pengamat sudah memperkirakan perdamaian Aceh akan bergerak ke arah buntu. Masalah utama adalah ketidakmampuan pemerintah Aceh melakukan tindakan-tindakan konkret, seperti pembangunan dan kesejahteraan, sebaliknya terkungkung pada isu keadilan (justice) dan martabat (dignity) yang bersifat simbolis. Bentuk keseriusan yang dimaksud adalah dengan fokus kepada amanah MoU Helsinki yang lebih urgent seperti (1) hasil bagi minyak bumi dan gas dan (2) pembentukan Komisi Kebenaran dan Rekonsiliasi (KKR).

Perlu disadari bahwa pengesahan Qanun Bendera dan Lambang Aceh ini tidak serta merta membuat seluruh rakyat Aceh menerimanya. Sebagian masyarakat Aceh merasa tidak terakomodir kepentingan etnis mereka dalam desain Bendera Aceh. Rakyat Aceh mencurigai pengesahan Qanun Bendera Aceh hanya menjadi simbol politik dan identitas politik satu golongan saja, yaitu mantan Kombatan GAM. Hal ini cukup mendasar 
mengingat Pemerintah Aceh dan Dewan Perwakilan Rakyat Aceh saat ini dikuasai oleh politisi dari Partai Aceh partai lokal yang menjadi kendaraan politik mantan kombatan GAM pascaMoU Helsinki. Polemik ini terus berlanjut dan cukup menguras tenaga, waktu, dan biaya. Perundingan demi perundingan dilakukan namun hanya menyisakan dead lock, sehingga harus dilakukan cooling down. Saat ini sudah tiga tahun cooling down dilakukan. Palagan politik di Aceh masih saja hangat dengan polemik Qanun Bendera Aceh, sampai pada ultimatum legislatif Aceh akan memboikot Pilkada 2017 jika Pemerintah Pusat tidak mengesahkan Qanun Bendera dan Lambang Aceh.

\section{Polemik Peraturan Daerah Dalam}

\section{Konstruksi Media}

Dalam pembicaraan konstruksi media dan polemik sebagai bagian dari dinamika politik lokal di era desentralisasi, penggunaan analisis framing menjadi mata pisau yang dianggap cukup tajam untuk membedah teks media. Pola kerja jurnalis tidak hanya dimaknai sebagai rutinitas biasa saja, melainkan sebuah proses yang kompleks serta membutuhkan profesionalitas kerja -lazim disebut sebagai proses redaksional. Dalam menentukan apakah suatu peristiwa memiliki nilai berita sesungguhnya merupakan tahap awal dari proses kerja redaksional. Biasanya seorang redaktur menentukan apa yang harus diliput, sementara seorang reporter menentukan bagaimana cara meliputnya, karena ia berurusan dengan tahap pencarian/penghimpunan dan penggarapan berita. Setelah seluruh materi terhimpun, maka dilakukanlah penulisan dan penyuntingan (editing). Dalam tahap akhir, sambil dilakukan penyuntingan, dilakukan pula pemerkayaan terhadap berita. Proses inilah yang dikenal sebagai konstruksi realitas media.

Proses kerja redaksional terjadi dalam polemik polemik pengesahan Qanun Nomor 03 Tahun 2013 tentang Bendera dan Lambang Aceh. Polemik ini mulai mengemuka di ruang publik setelah diketahui bahwa substansi Bendera dan Lambang Aceh menyerupai Bendera dan Lambang GAM. Situs online antaranews.com mulai merespon dengan memunculkan pemberitaan pasca-pengesahan dalam berbagai judul dan sudut penekanan berita.

Dalam melihat dan menginterpretasikan polemik Pemerintah Pusat dan Pemerintah Aceh terkait pengesahan Qanun Bendera dan Lambang Aceh, situs berita online antaranews.com menggunakan frame 
"Bendera Aceh mengadopsi Bendera GAM dan harus direvisi". Hal ini terlihat melalui kutipan berita berikut:

“... Bendera Aceh yang qanunnya disahkan DPRA pada 23 Maret 2013 itu ketika Aceh masih dilanda konflik bersenjata atau sebelum perjanjian yang ditandatangani di Helsinki 15 Agustus 2005 merupakan salah satu simbol perjuangan Gerakan Aceh Merdeka

(GAM).”

(antaranews.com/26 Maret 2013, pukul 19.09 WIB).

“... Yang namanya perda atau qanun itu tidak boleh bertentangan dengan peraturan perundangan yang lebih tinggi ataupun kepentingan umum." kata Juru Bicara Kementerian Dalam Negeri, Reydonnyzar Moenek, usai sidang pengujian UU Pembentukan Pemda Kalimantan Utara di Mahkamah Konstitusi (MK) Jakarta, Rabu. (antaranews,com/27 Maret 2013, pukul 22:43 WIB).

"... Setelah DPRA menyetujui qanun (peraturan daerah) mengenai bendera Aceh dan kemudian dikibarkan di ruang publik, menimbulkan berbagai persoalan sosial. Apalagi bendera tersebut mirip dengan organisasi separatis di Aceh," katanya (Priyo Budi Santoso -pen). (antaranews.com/05 April 2013, pukul 19.26 WIB).

Melalui frame ini antaranews.com menginterpretasikan bahwa terjadinya polemik terhadap Qanun Bendera dan Lambang Aceh karena substansi Qanun yang disahkan oleh Pemerintah Aceh dan DPRA tersebut bertentangan dengan peraturan yang lebih tinggi. Dalam Pasal 6 butir 4 PP No. 77 Tahun 2007 tentang Lambang Daerah dimana disebutkan bahwa desain logo dan bendera daerah tidak boleh mempunyai persamaan pada pokoknya atau keseluruhannya dengan desain logo dan bendera organisasi terlarang atau organisasi/perkumpulan/lembaga/geraka n separatis dalam Negara Kesatuan Republik Indonesia.

Media memiliki ketajaman untuk melihat peristiwa yang mengandung nilai berita. Conflict dan Controvercy menjadi nilai berita yang sangat laku dipasaran (Weldon, 2009; Cramer, 2011). Peristiwa pengesahan Qanun Bendera dan Lambang Aceh dimaknai media sebagai bentuk keberanian Pemerintah Aceh. Keberanian ini muncul karena kursi Pemerintah Aceh dan DPRA dikuasai dan didominasi oleh mantan kombatan GAM.

Untuk memperkuat konstruksinyanya, situs berita online antaranews.com memakai metaphors "jangan sampai 
luka lama terkoyak kembali, akibat pengesahan Bendera GAM sebagai Bendera Aceh". Hal ini sesuai dengan kutipan berita berikut:

"Jangan sampai luka lama terkoyak kembali, desain bendera GAM mengingatkan semua pihakkepada masa lalu, mari kita menatap ke depan. Kita ubah sedikit desainnya agar memori itu tidakterbayang kembali," ungkapnya. (antaranews.com/04 April 2013, pukul 20:07 WIB).

Sikap Pemerintah Aceh yang mengesahkan Qanun Bendera dan Lambang Aceh bukan merupakan sikap patriotik. Meskipun Aceh memiliki kewenangan melalui UU Pemerintah Aceh dan disepakati dalam MoU Helsinki, namun Pemerintah Pusat tidak sepakat dengan desain Bendera Aceh yang menyerupai Bendera GAM. Media melihat sikap Pemerintah Aceh ini akan berdampak pada terkoyaknya kembali luka lama yang dialami oleh rakyat Aceh selama konflik berlangsung. Mungkin saja sebagian masyarakat Aceh medukung kehadiran Bendera Aceh dengan desain Bendera GAM ini, namun yang tidak boleh dilupakan bahwa ada rakyat Aceh yang tidak mendukung bahkan membakar Bendera Aceh tersbut. Oleh media, hal ini disoroti sebagai bentuk inkonsistensi Pemerintah
Aceh dalam program mensejahterakan rakyat Aceh. Elite politik Aceh lebih memilih menghabiskan energi untuk sebuah Bendera dari pada menuntaskan visi pembangunan Aceh pasca-tsunami dan konflik.

Dalam catchphrases, situs berita online antaranews.com menyebutkan Bendera Gerakan Aceh Merdeka (GAM) yang dulu digunakan saat konflik disahkan oleh DPRA dan Pemerintah Aceh menjadi Bendera Daerah. Frase kontras ini digunakan oleh antaranews.com untuk memperkuat frame yang semula bahwa substansi Qanun Bendera dan Lamban Aceh mengadopsi Bendera dan Lambang GAM.

“... Menurut dia (Reydonnyzar Moenek-pen), lambang daerah tidak boleh menyerupai gerakan separatis, seperti di Papua, Maluku, atau GAM di Aceh. "Itu tidak diperbolehkan menyerupai atau menginspirasikan," katanya. (antaranews.com/27 Maret 2013, pukul 22.43 WIB).

Catchphrases yang dipakai oleh antaranews.com dikutip dari pernyataan Juru Bicara Kementerian Dalam Negeri, Reydonnyzar Moenek. Pemilihan narasumber yang cenderung berasal dari perwakilan Pemerintah Pusat membuat konstruksi yang dibangun oleh 
antaranews.com hanya memihak pada satu sudut pandang saja. Situs online antaranews.com terlihat seperti mengabaikan pendapat dari elite lokal di Aceh, jika pun ada pendapat tersebut pasti diarahkan kepada kontra pengesahan Qanun Bendera dan Lambang Aceh.

Exemplars yang dipakai oleh situs online antaranews.com menyatakan bahwa Bendera Aceh mirip Bendera GAM. Exemplars ini dipakai hampir dalam setiap berita antaranews.com, bahkan Pemerintah Aceh dianggap melanggar kesepakatan dengan Pemerintah Pusat serta tokoh politik dan tokoh hukum nasional, karena masih mengesahkan Bendera GAM sebagai Bendera Aceh. Hal ini terlihat dalam kutipan berita berikut:

“... Menurut Yusril, penetapan bendera milik GAM itu melanggar kesepakatan dari pertemuan konsultasi antara Gubernur Aceh dengan sejumlah pejabat Pemerintah termasuk unsur Kementerian Dalam Negeri (Kemendagri), mantan Wakil Presiden Jusuf Kalla, Wakil Ketua MPR Ahmad Farhan Hamid, dan Wakil Ketua DPR Priyo Budi Santoso, di Hotel Sultan, Jakarta pada 17 Desember 2012." (antaranews.com/02 April 2013 21:05 WIB).

Penggunaan exemplars Bendera Aceh mirip Bendera GAM memiliki konsekuensi pada definisi publik terhadap polemik pengesahan ini. Terbentuknya opini publik bahwa Aceh sudah merdeka atau Aceh kembali kepada kondisi konflik yang telah berlangsung selama 30 tahun dan menelan korban ribuan jiwa. Pemerintah Pusat juga dicitrakan sebagai pihak yang "tertipu" akibat ulah elite politik di DPRA dan Pemerintah Aceh. Sementara itu, Pemerintah Aceh memiliki citra positif sebagai pihak yang berani "melawan" kebijakan Pemerintah Pusat sehingga memiliki posisi tawar yang besar vis a vis Pemerintah Pusat (International Crisis Group, 2013).

Situs berita online antaranews.com menggunakan depiction "Gerakan Separatis. Depiction ini ditemukan hampir disetiap pemberitaannya dan dipakai guna mengulang memori kolektif publik bahwa Gerakan Aceh Merdeka (GAM) merupakan gerakan separatis yang ada di Aceh. Tujuan dari gerakan separatis ini adalah memerdekakan Aceh dari Republik Indonesia. Dasar dari pemberontakan GAM adalah ketimpangan kesejahteraan yang diterima rakyat Aceh karena pola pemerintahan yang sentralistik yang 
dijalankan oleh Pemerintah Pusat. Depiction ini memperkuat frame antaranews.com dalam mengonstruksi Qanun Bendera dan Lambang Aceh tidak bisa diterima dengan alasan apapun lantaran substansi Qanun yang bermasalah.

Memperkuat frame-nya, situs berita online antaranews.com menggunakan visual images yang menampilkan foto-foto aksi massa mendukung Qanun Bendera dan Lambang Aceh, foto aksi massa menolak Qanun Bendera dan Lambang Aceh, gambar Bendera Indonesia, dan foto beberapa narasumber. Foto aksi massa pendukung Qanun Bendera dan Lambang Aceh ditampilkan antaranews.com dengan point of view desain Bendera dan Lambang Aceh, hal ini dilakukan untuk mempertegas konstruksi bahwa Bendera Bulan Bintang ala GAM dijadikan oleh Pemerintah Aceh sebagai bendera daerah.

Desain Bendera Bulan Bintang menimbulkan trauma bagi rakyat Aceh. Konflik selama hampir 30 (tiga puluh) tahun membuat rakyat Aceh sengsara. Penggunaan simbol identitas GAM barupa bendera dan lambang melekat kuat di benak dan pikiran rakyat Aceh. Bagi rakyat Aceh, Bendera Bulan Bintang dan Lambang Buraq Singa merupakan simbol gerakan pemberontak baik secara langsung maupun tidak langsung telah membuat rakyat Aceh berada dalam situasi yang tidak nyaman karena konflik. Oleh karena itu, jika Pemerintah Aceh dan DPRA yang didominasi oleh mantan kombatan GAM bersikeras menggunakan simbol Bulan Bintang dan Buraq-Singa maka konflik baru di masyarakat tidak bisa dielakkan. Konflik bisa saja terjadi karena realitasnya tidak semua rakyat Aceh setuju dengan Bendera Bulan Bintang dan Lambang Buraq-Singa.

Penolakan sebagian rakyat Aceh terhadap Qanun Bendera dan Lambang Aceh ditunjukkan antaranews.com dengan menampilkan berita dan fotofoto aksi massa. Foto-foto tersebut mengambil point of view pada aksi massa mengibarkan Bendera Merah Putih dan membakar Bendera Bulan Bintang. Bagi massa -seperti konstruksi yang dibangun antaranews.com- tidak boleh ada bendera lain yang berkibar di Aceh selain Bendera Merah Putih, meskipun antaranews.com menyadari bahwa Bendera dan Lambang Aceh merupakan identitas keistimewaan bagi Aceh yang berakar pada sejarah kegemilangan Kesultanan Aceh masa lalu.

Untuk reasoning device (perangkat penalaran) situs berita online 
antaranews.com memakai roots Qanun Bendera dan Lambang Aceh yang disahkan oleh DPRA dan Pemerintah Aceh melanggar aturan perundangundangan yang lebih tinggi, yaitu, Peraturan Pemerintah Nomor 77 Tahun 2007 tentang Lambang Daerah. Antaranews.com juga memberikan penekanan teks bahwa Pemerintah Aceh mengadopsi simbol GAM. Sebagai appeals to principles, situs berita online antaranews.com juga menyatakan bahwa desain Bendera dan Lambang Aceh yang menyerupai lambang GAM membuat semua pihak kembali kepada ingatan masa lalu saat konflik terjadi di Aceh.

Situs berita online antaranews.com berspekulasi bahwa identitas simbolik rakyat Aceh yang tertuang dalam Qanun Bendera dan Lambang Aceh akan membuat ingatan publik kembali kepada masa konflik. Bukan kemajuan yang akan didapatkan oleh rakyat Aceh. Rakyat Aceh punya kenangan tersendiri terhadap simbol-simbol tersebut. Kenangan tersebut bisa berupa nostalgia pada perjuangan masa lalu atau justru membuat rakyat Aceh tertekan secara psikologis. Hal ini yang seharusnya dihindari oleh Pemerintah Aceh dan DPR Aceh demi menciptakan kepentingan bersama.

Untuk memperkuat bingkainya, situs online antaranews.com memakai consequences bahwa Pemerintah Pusat dan Pemerintah Aceh harus berunding guna mencari jalan keluar untuk penyelesaian polemik Qanun Bendera dan Lambang Aceh. Situs berita online antaranews.com memandang melalui dialog yang melibatkan kedua belah pihak, jalan keluar penyelesaian polemik ini akan segera berakhir. Masing-masing pihak perlu menurunkan tensi guna mendapatkan solusi yang baik bagi kemaslahatan rakyat Aceh dan kedaulatan Republik Indonesia.

Situs berita online antaranews.com mengonstruksi realitas dampak yang akan ditimbulkan jika Pemerintah Aceh tetap bersikeras mempertahankan Qanun Bendera dan Lambang Aceh. Dampak paling besar yang timbul adalah desakan pemekaran wilayah Aceh menjadi tiga propinsi. Dengan berpisahnya Aceh menjadi tiga propinsi baru, akan menyulitkan posisi GAM yang saat ini menguasai pemerintah di Aceh. Pemerintah Aceh akan dianggap gagal memberikan jaminan persatuan dan kesatuan seluruh rakyat Aceh sesuai MoU Helsinki dan UU Pemerintah Aceh.

\section{KESIMPULAN}

Dalam relasinya dengan politik, ada dua kemungkinan yang akan dilakukan media yaitu, (1) menjadi agent 
of control kekuasaan atau (2) menjadi pembela kekuasaan. Kondisi ini telah membuat posisi dilematis bagi media. Media -termasuk di dalamnya jurnalisberada dalam tekanan yang sangat besar baik dari rutinitas dan ideologi media maupun dari pemilik dan pihak eksternal media yang biasanya memiliki pengaruh besar. Berbagai tekanan ini telah memaksa media masuk dalam ranah pragmatis serta tidak jarang bertentangan dengan standar nurani. Ketidakberdayaan media dan jurnalis juga disebabkan oleh tekanan ekonomipolitik media yang memaksa media masuk ke ranah pragmatis.

Framing menjadi alat bagi media untuk mengonstruksi realitas politik yang sangat kompleks. Proses ini telah menjadi rutinitas media dan dianggap merupakan prosedur standar bagi kerjakerja di ruang redaksi. Framing memiliki dampak yang cukup besar bagi citra elite politik. Hal ini dikarenakan framing dapat membentuk opini publik dan mengarahkannya sesuai tujuan media dan elite politik.

Pusaran kontroversi Qanun Bendera dan Lambang Aceh media situs online antaranews.com mengonstruksi realitas bahwa kewenangan Aceh untuk memiliki bendera dan lambang daerah dapat mengganggu stabilitas keamanan dan kedaulatan Republik Indonesia. Hal ini dapat dilihat dari frame central (package) yang digunakan, yaitu, Qanun Bendera dan Lambang Aceh menyerupai Bendera GAM dan bertentangan dengan aturan hukum yang berlaku dalam NKRI. Tidak hanya bertentangan dengan Peraturan Pemerintah Nomor 77 Tahun 2007, namun juga bertolakbelakang dengan MoU Helsinki dan Undang-Undang Nomor 11 Tahun 2006 tentang Pemerintah Aceh.

Wartawan dan para redaktur sangat berperan dalam proses konstruksi media, khususnya dalam pemberitaan polemik pengesahan Qanun Bendera dan Lambang Aceh. Para pekerja media (wartawan) selalu patuh pada tugasnya untuk menyeleksi isu yang laik diangkat dan menyusun pelbagai langkah bagaimana suatu fakta ditonjolkan. Proses seleksi isu ini terjadi dalam rapatrapat internal redaksi, seperti rapat perencanaan dan rapat evaluasi. Dalam setiap rapat ini, pemimpin dalam keredaksian punya kuasa penuh dalam menentukan sikap dan arah keberpihakan media. Sedangkan penonjolan fakta dilakukan oleh redaktur di masing-masing desk-nya. Redaktur ibarat tukang "jahit” yang mengotak-atik berita lalu memilih dan memilah mana yang akan ditonjolkan serta mana yang 
harus dihilangkan. Proses konstruksi ini dengan sendirinya akan mendistorsi netralitas dan objektifitas berita. Media mem-blow up berita melebihi kapasitasnya sebagai penyampai informasi. Media ikut serta dalam pusaran polemik dengan memihak kepada Pemerintah Pusat, melalui pemberian ruang yang lebih besar kepada narasumber dari Pemerintah Pusat dan politisi di DPR-RI. Kondisi ini tentunya tidak menguntungkan bagi Pemerintah Aceh. Pemerintah Aceh menjadi pihak yang sangat bersalah. Seharunya media memberi ruang yang sama besar, sehingga masyarakat mampu mengolah informasi seputar polemik ini dengan baik.

\section{DAFTAR PUSTAKA}

Aspinall, Edward. 2005. The Helsinki Agreement: A More Promising Basis for Peace in Aceh?. Policy Studies 20. East-West Center Washington.

Awaludin, Hamid. 2009. Peace in Aceh: Notes on the Peace Process between the Republic of Indonesia and the Aceh Freedom Movement (GAM) in Helsinki. Jakarta: CSIS.

Badara, Aris. 2012. Analisis Wacana; Teori, Metode, dan Penerapannya pada Wacana Media. Jakarta: Kencana Prenada Media Group.

Birkland, Thomas A. Dan Regina G. Lawrence. 2009. Media Framing and Policy Change After Columbine. American
Behavioral Scientist Volume 53 Number 10.

Castells, Manuel. 2001. The Rise of The Network Society. Oxford: Blackwell.

Cramer, Peter A. 2011. Controvercy as News Discourse. Canada: Springer.

Djumala, Darmansjah. 2013. Soft Power Untuk Aceh; Resolusi Konflik dan Politik Desentralisasi. Jakarta: Gramedia Pustaka Utama.

Entman, Robert N. 1993. Framing: Toward Clarification of Fractured Paradigm. Journal of Communication Vol. 43. International Communication Association.

Entman, Robert N. 2007. Framing Bias: Media in the Distribution of Power. Journal of Communication vol. 57 (2007). International Communicaton Association.

Eriyanto. 2012. Analisis Framing: Konstruksi, Ideologi, dan Politik Media. Jogjakarta: LKiS.

Fahrimal, Yuhdi et al. 2014. Framing Media Terkait Polemik Pengesahan Qanun Bendera dan Lambang Aceh. Jurnal Analisis, Desember 2014, Vol.3, No. 02. Universitas Hasanuddin.

Fiske, John. 2012. Pengantar Ilmu Komunikasi. (Penj. Hapsari Dwiningtyas). Jakarta: Rajawali Press.

Fuady, Muhammad E. 2002. Surat Kabar Digital Sebagai Media Konvergensi di Era Digital. Jurnal Mediator Vol. 3 No. 1.

Hardiman, Budi F. 2010. Komersialisasi Ruang Publik Menurut Hannah Arendt dan Jurgen Habermas. Dalam F. Budi Hardiman (Ed.).2010. Ruang Publik; Melacak "Partisipasi 
Demokratis dai Polis sampai Cyberspace. Yogyakarta: PT. Kanisius.

International Crisis Group. 2013. "Indonesia: Tensions Over Aceh's Flag". Asia Briefing No. 39. Jakarta/Brussel, 7 May 2013.

Ishadi SK. 2014. Media dan Kekuasaan: Televisi di Hari-Hari Terakhir Soharto. Jakarta: Penerbit Buku Kompas.

Jerit, Jennifer. 2007. Issue Framing and Engagement: Rhetorical Strategy in Public Policy Debates. Political Behavior (2008) 30 .

Kingsbury, Damien. 2005. A Mechanism to End Conflict in Aceh. Journal Security Challenges Volume 1 Number 1 (2005).

Kovach, Bill dan Tom Rosientiel. 2001. The Elements of Journalism: What People Should Know and The Public Should Expect. New York: Crown Pubisher.

Lee, Nam-Jin, Douglas M.McLeod, dan Dhavan V. Shah. 2008. Framing Policy Debates: Issue Dualism, Journalistic Frames, and Opinions on Controversial Policy Issues. Communication Research Volume 35, Number 5, October 2008. SAGE Publications.

Manan, Abdul. 2010. Ancaman Itu Datang dari Dalam. Jakarta: Aliansi Jurnalis Independen.

McNair, Brian. 2011. An Introdution to Political Communication (Fifth Edition). New York: Routledge).

Meyer, Thomas. 2002. Media Democracy: How Media Colonized Politics?. Cambridge: Polity Press.

Mosco, Vincent. 2009. The Political Economy of Communication
(Second Edition). Thousand Oaks: SAGE Publication.

Nurhasim, Moch. 2008. Konflik dan Integrasi Politik Gerakan Aceh Merdeka; Kajian Tentang Konsensus Normatif antara RIGAM dalam Perundingan Helsinki. Jogjakarta: Pustaka Pelajar dan Pusat Penelitian Politik-LIPI.

Nurhasim, Ahmad et al. 2009. Wajah Retak Media: Kumpulan Laporan Penulusuran. Jakarta: Aliansi Jurnalis Independen

Nyarwi. 2008. Kebebasan Pers dan Kepentingan Publik. Jurnal Ilmu Komunikasi, Volume 9, Nomor 1, Januari-April 2011.

Rahardjo, Turnomo. 2008. Bersikap Partisan di Ruang Publik. Jurnal KOMUNIKA Vol. 11, No. 1, 2008. Lembaga Ilmu Pengetahuan Indonesia.

Scheufele, D.A. 1999. Framing as a Theory of Media Effects. Journal of Communication, 49 (1).

Scheufele, Dietram A. dan David Tewksbury. 2007. Framing, Agenda Setting, and Priming: The Evolution of Three Media Effetcs Models. Journal of Communication 57. International Communication Association.

Shoemaker, Pemela J. dan Stephen D. Reese. 1996. Mediating The Message: Theories of Influences on Mass Media Contents (Second Edition). New York: Longman Publishers.

Straubhaar, LaRose dan Davenport. 2012. Media Now: Understanding Media, Culture, and Technology (Seventh Edition). Boston: Wadsworth CENGAGE Learning.

Subiakto, Henry dan Rachmah Ida. 2012. Komunikasi Politik, 
Media, danDemokrasi. Jakarta:

Kencana Prenada Media Group.

Sujatmiko, Iwan Gardono. 2012.

Conflict Transformation and

Social Reconciliation: The Case

of Aceh, Indonesia. Journal

Asian Social Science Vol. 8, No.

2, February 2012.

Van Gorp, Baldwin. 2007. The

Constructionist Approach to

Framing: Bringing Culture Back

In. Journal of Communication 57 (2007).

Weaver, David H. 2007. Thoughts on Agenda Setting, Framing, and Priming. Journal of Communication 57 (2007).

Weldon, Michele. 2009. The Changing Nature of News. Dalam William F. Eadie, 21st Century Communication: A Reference Handbook. California: SAGE Publication.

Young, Lori dan Stuart Soroka. 2012. Affective News: The Automated Coding of Sentiment in Politicial Text. Political Communication (29). 